\title{
Penerapan Sistem Pakar Menggunakan Metode Nearest Neighbor Mendiagnosa Gangguan Kesehatan Pengguna Minuman Keras
}

\author{
Lince T Sianturi, Tegar Sabatia Tarigan \\ Program Studi Teknik Informatika, STMIK Budi Darma, Medan, Indonesia \\ Jalan Sisingamangaraja No. 338 Medan, Indonesia
}

\begin{abstract}
Abstrak
Sistem pakar (expert system) secara umum adalah sistem yang berusaha mengadopsi pengetahuan manusia ke komputer, agar komputer dapat menyelesaikan masalah seperti yang biasa dilakukan oleh para ahli. Atau dengan kata lain sistem pakar adalah sistem yang didesain dan diimplementasikan dengan bantuan bahasa pemrograman tertentu untuk dapat menyelesaikan masalah seperti yang dilakukan oleh para ahli. Diharapkan dengan sistem ini, orang awam dapat menyelesaikan masalah tertentu baik 'sedikit' rumit ataupun rumit sekalipun 'tanpa' bantuan para ahli dalam bidang tersebut. Sedangkan bagi para ahli, sistem ini dapat digunakan sebagai asisten yang berpengalaman. Sistem ini melakukan diagnosa jenis gangguan kesehatan pengguna minuman keras berdasarkan dari gejala-gejala yang diinputkan ke sistem. Aplikasi yang dikembangkan ini bertujuan untuk menentukan pengguna minuman keras yang konsumsi dengan hanya memperhatikan kriteria-kriteria yang dialami oleh pengguna minuman keras. Dengan menggunakan Metode Nearest Neighbor mampu menunjukkan ukuran kepastian terhadap suatu fakta dari kriteria-kriteria yang ada. Keluaran sistem berupa hasil penelusuran pengguna minuman keras digunakan oleh pengguna berdasarkan gejala.
\end{abstract}

Kata kunci: Sistem Pakar, Minuman Keras, Metode Nearest

\section{Abstract}

Expert systems in general are systems that try to adopt human knowledge to computers so that computers can solve problems as is usually done by experts. Or in other words an expert system is a system that is designed and implemented with the help of certain programming languages to be able to solve problems as done by experts. It is expected that with this system, lay people can solve certain problems, either 'a little' complicated or even complicated 'without' the help of experts in the field. As for experts, this system can be used as an experienced assistant. This system diagnoses the types of health problems of liquor users based on the symptoms entered into the system. This developed application aims to determine which liquor users consume by only paying attention to the criteria experienced by liquor users. Using the Nearest Neighbor Method is able to show a measure of certainty about a fact from the existing criteria. System output in the form of search results for liquor users is used by users based on symptoms.

Keywords: Expert System, Liquor, Nearest Method

\section{PENDAHULUAN}

Sistem pakar (expert system) adalah sistem yang berusaha mengadopsi pengetahuan manusia ke komputer yang dirancang untuk memodelkan kemampuan menyelesaikan masalah seperti layaknya seorang pakar. Dengan sistem pakar ini, orang awam pun dapat menyelesaikan masalahnya atau hanya sekedar mencari suatu informasi berkualitas yang sebenarnya hanya dapat diperoleh dengan bantuan para ahli di bidangnya. Dalam penyusunannya, sistem pakar mengkombinasikan kaidah-kaidah penarikan kesimpulan (inference rules) dengan basis pengetahuan tertentu yang diberikan oleh satu atau lebih pakar dalam bidang tertentu.

Pengguna minuman keras saat ini semakin banyak di kalangan masyarakat, dari kalangan atas sampai kalangan bawah. Sehingga banyak juga kasus-kasus gangguan kesehatan pengguna minuman keras bahkan sampai merenggut nyawa pengguna minuman keras. Minuman keras/beralkohol adalah minuman yang mengandung etanol. Etanol adalah bahan psikoaktif dan mengkonsumsinya menyebabkan penurunan kesadaran. Masalah gangguan kesehatan yang dialami pengguna biasanya mencakup bagian-bagian organ pencernaan, bahkan dapat menyebar ke bagian-bagian organ vital tubuh manusia, misalnya kinerja otak, jantung, paru-paru, lambung dan lain-lain.

Berdasarkan penelitian sebelumnya yang dilakukan Mei Lestari menyimpulkan bahwa Metode Nearest Nreighbor merupakan metode yang baik dalam mesin pembelajaran berdasarkan data[1], dengan menggunakan probabilitas bersyarat sebagai dasarnya. Metode ini juga metode untuk menghasilkan estimasi parameter dengan menggabungkan informasi dari sampel dan informasi lain yang telah tersedia sebelumnya ke dalam proses analisa data, proses ini diawali dengan distribusi probabilitas yang sudah ada diberikan untuk himpunan data yang dipertimbangkan. Maka dari itu kasus ini cocok di gunakan untuk mendiagnosa gangguan kesehatan pengguna minuman keras.

Dengan menggunakan Metode Algoritma Nearest Neighbor, peneliti dapat menganalisa gangguangangguan kesehatan dan gejala-gejala yang dialami pengguna minuman keras dan apa dampaknya bagi pengguna minuman keras pada kesehatannya dengan cara menganalisa atau mewawancarai pasien yang datang kerumah sakit untuk mengatahui apa yang sebenarnya yang dialami pasien atas gejala-gejala yang dialaminya setelah mengkonsumsi minuman keras menggunakan perbandingan kasus sebelumnya. Penarikan kesimpulan (inference rules) dengan basis pengetahuan tertentu yang diberikan oleh satu atau lebih pakar dalam bidang tertentu. Setelah mendapatkan hasil gejala dari pasien maka peneliti dapat melakukan pengidentifikasian atau mencocokkan atas 
gejala yang dilaminya dengan kasus yang sebelumnya. Kombinasi dari kedua hal tersebut disimpan dalam komputer, yang selanjutnya digunakan dalam proses pengambilan keputusan untuk mengetahui apa dampak gejala yang dialaminya setelah mengkonsumsi minuman keras.

\section{TEORITIS}

\subsection{Sistem Pakar}

Sistem pakar merupakan suatu program aplikasi komputerisasi yang berusaha menirukan proses penalaran dari seorang ahlinya dalam memecahkan masalah spesifikasi atau bisa dikatakan merupakan duplikat dari seorang pakar karena pengetahuannya disimpan didalam basis pengetahuan untuk diproses pemecahan masalah[2]. Data yang tersimpan dalam database akan menginformasikan suatu keluhan pasien dengan akurat dan dapat menyimpulkan jenis penyakit yang diderita oleh pasien[8][10-12].

\subsection{Nearest Neighbor}

K-Nearest Neighbor (KNN) termasuk kelompok instance-based learning. Algoritma ini juga merupakan salah satu teknik lazy learning[6]. KNN dilakukan dengan mencari kelompok k objek dalam data training yang paling dekat (mirip) dengan objek pada data baru atau data testing. Algoritma K-Nearest Neighbor adalah sebuah metode untuk melakukan klasifikasi terhadap objek berdasarkan data pembelajaran yang jaraknya paling dekat dengan objek tersebut. Nearest Neighbor adalah pendekatan untuk mencari kasus dengan menghitung kedekatan antara kasus baru dan kasus lama yaitu berdasarkan pada pencocokan bobot dari sejumlah fitur yang ada.

Menurut Watson(1997) demikian juga menurut Kusrini dan Luthfi (2009) kimiripan dapat ditentukan menggunakan Rumus 1[7]

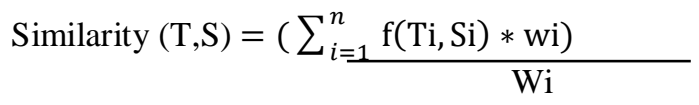

Dimana:

T: Kasus baru

S: Kasus lama yang tersimpan dalam data base

$\mathrm{N}$ : Jumlah atribut dalam setiap kasus

i: Atribut individu antara $1 \mathrm{~s} / \mathrm{d} \mathrm{n}$

f: Fungsi similarity atribut i antara kasus $\mathrm{T}$ dan kasus $\mathrm{S}$

w: Bobot yang diberikan pada atribut ke-i

$\operatorname{Jarak}=\frac{(a * b)+(c * d)+\left(e^{*} f\right)+\ldots+(n * n)}{b+d+f+\ldots+n}$

\subsection{Minuman Keras}

Minuman keras adalah minum-minuman beralkohol yang dapat menyebabkan si peminum mabuk dan hilang kesadarannya[8]. Minuman beralkohol ini dapat merusak pikiran, sehingga orang menjadi tidak sewajarnya atau tidak normal. Minuman keras-beralkohol adalah minuman yang mengandung etanol. Etanol adalah bahan psikoaktif dan konsumsinya menyebabkan penurunan kesadaran. Di berbagai negara, penjualan minuman kerasberalkohol dibatasi ke sejumlah kalangan saja, umumnya orang-orang yang telah melewati batas usia tertentu.

Mengkonsumsi minuman keras adalah salah satu bentuk penyimpangan social[8]. Faktor penarik berada di luar diri seseorang, sedangkan faktor pendorong berasal dari dalam diri atau keluarga yang memungkinkan seseorang untuk melakukan penyimpangan tersebut. Lebih lanjut bahwa penyimpangan-penyimpangan tersebut terjadi akibat sosialisasi yang tidak sempurna baik pergaulan di masyarakat maupun kehidupan di dalam keluarga yang dianggapnya tidak memuaskan.

Sehingga anak mencari pelarian di luar rumah dengan mencari teman yang dapat memberikan perlindungan dan pengakuan akan keberadaan dirinya. Pada penyimpangan yang dilakukan melalui penyalahgunaan narkoba dan minuman keras, biasanya seseorang tidak akan langsung melakukannya, akan tetapi diajak oleh teman sekelompoknya untuk mencoba lebih dahulu untuk membuktikan bahwa mereka telah menjadi orang dewasa, lama kelamaan seseorang akan mendapatkan pengakuan dari kelompoknya.

Adapun gejala yang di timbulkan mengkonsumsi minuman keras bagi pengguna[9] adalah sebagai berikut: 1. Gangguan Mental Organik (GMO)

Gangguan ini akan mengakibatkan perubahan perilaku, seperti bertindak kasar, gampang marah sehingga memiliki masalah dalam lingkungan sekitar. Perubahan fisiologi seperti muka merah dan jalan sempoyongan.

Perubahan psikologi seperti susah konsentrasi, sering ngelantur dan gampang tersinggung.

2. Merusak Daya Ingat

Kecanduan minuman keras dapat menghambat perkembangan memori dan sel-sel otak.

3. Oedema Otak 
Pembengkakan dan terbendungnya darah di jaringan otak. Sehingga mengakibatkan gangguan koordinasi dalam otak secara normal.

4. Sirosis Hati

Peradangan sel hati secara luas dan kematian sel dalam hati akibat terlalu banyak minum minuman keras.

5. Gangguan Jantung

Terlalu banyak minum minuman keras dapat membuat kerja jantung tidak berfungsi dengan baik.

6. Gastrinitis

Radang atau luka pada lambung. Ini biasanya diakibatkan karena muntah akibat minuman keras.

\section{ANALISA DAN PEMBAHASAN}

Pengguna minuman keras dapat dideteksi dari kriteria-kriteria yang ditimbulkan akibat mengkonsumsi minuman keras, hal tersebut biasanya selalu berhubungan dengan perubahan baik fisik maupun perilaku yang ditimbulkan oleh pengguna minuman keras. Untuk mengetahui seseorang merupakan pengguna minuman keras, maka dibutuhkan suatu program sistem pakar, dimana sistem tersebut dapat mengenali tingkat penggunaan minuman keras yang ditimbulkan berdasarkan kriteria-kriteria yang ditimbulkan oleh pengguna minuman keras. Berikut adalah tabel kriteria yang ditimbulkan dari penggunaan minuman keras yang dialami oleh pengguna yaitu:

Tabel 1. Kriteria Gejala Pengguna Minuman Keras

\begin{tabular}{cl}
\hline No & \multicolumn{1}{c}{ Gejala } \\
\hline 1 & Mulut berbau minuman keras \\
2 & Pusing \\
3 & Sempoyongan \\
4 & Mudah emosi \\
5 & Mual-mual \\
6 & Muntah-muntah \\
7 & Berbicara tidak menentu \\
8 & Gelisah \\
9 & Sering gemetar \\
10 & Wajah kemerah-merahan \\
11 & Penglihatan menurun \\
12 & Kesulitan bernafas \\
13 & Jantung berdetak kencang \\
14 & Kesulitan menelan dan berbicara \\
15 & Muntah darah \\
16 & Wajah bengkak hitam pucat \\
& $\quad$ Sumber: dr.M Sitepu,2017[9]
\end{tabular}

Dari tabel di atas, untuk mempermudah dalam penghitungan nilai Atributnya berikut ini adalah tabel bobot dari atribut tersebut:

Tabel 2. Nilai Bobot Gejala

\begin{tabular}{ll}
\hline \multicolumn{1}{c}{ Gejala } & Bobot \\
\hline Mulut berbau minuman keras & 0,9 \\
Pusing & 0,9 \\
Sempoyongan & 0,8 \\
Mudah emosi & 0,8 \\
Mual-mual & 0,7 \\
Muntah-muntah & 0,7 \\
Berbicara tidak menentu & 0,9 \\
Gelisah & 0,5 \\
Sering gemetar & 0,4 \\
Wajah kemerah-merahan & 0,6 \\
Penglihatan menurun & 0,4 \\
Kesulitan bernafas & 0,7 \\
Jantung berdetak kencang & 0,9 \\
Kesulitan menelan dan berbicara & 0,4 \\
Muntah darah & 0,3 \\
Wajah bengkak hitam pucat & 0,1 \\
\hline
\end{tabular}

Pada penderita pengguna minuman keras memiliki beberapa tingkatan pengguna antara lain: 
Tabel 3. Tingkatan Gangguan Kesehatan

\begin{tabular}{cc}
\hline Tingkatan & Persen \\
\hline Ringan & $0-50 \%$ \\
Sedang & $51-80 \%$ \\
Berat & $81-100 \%$ \\
\hline
\end{tabular}

Dari kriteria tersebut maka ditentukan nilai yang akan menentukan probabilitas pengguna minuman keras (beralkohol) yang dapat dilihat pada tabel dibawah ini:

\begin{tabular}{lc}
\multicolumn{2}{c}{ Tabel 4. Kedekatan Nilai Atribut } \\
\hline \multicolumn{1}{c}{ Tingkat } & Bobot \\
\hline Ya-Ya & 1 \\
Tidak - Tidak & 0 \\
Ya - Tidak & 0,25 \\
Tidak - Ya & 0,5
\end{tabular}

Sistem pakar adalah program dengan basis pengetahuan yang dinamis. Dengan demikian, diperlukan pengetahuan yang diakuisisi menjadi basis pengetahuan dengan mengetahui terlebih dahulu bagaimana mengenali suatu pengguna minuman keras yang terjadi berdasarkan kriteria yang ditimbulkan.

Pada aplikasi sistem pakar untuk mendiagnosa pengguna minuman keras dengan menggunakan Metode Nearest Neighbor yaitu metode pengukuran peluang dari setiap keputusan yang diambil, dimana program mengambil keputusan dari jawaban "Ya" atau "Tidak" atas pertanyaan yang digunakan dari program dan perhitungan probabilitas dari kriteria-kriteria yang ditimbulkan kemampuan sistem pakar memecahkan masalah tergantung pada seberapa luas basis penegetahuannya. Sehingga pada akhirnya analisa didapat hasil berupa sebuah sistem yang strukturnya dapat didefinisikan dengan baik dan jelas.

\subsection{Penerapan Metode Nearest Neighbor}

Metode Nearest Neighbor merupakan metode yang baik di dalam mesin pembelajaran berdasarkan data training , dengan menggunakan probabilitas bersyarat sebagai dasarnya. Metode Nearest Neighbor merupakan satu metode yang digunakan untuk menghitung ketidakpastian data menjadi data yang pasti dengan membandingkan antara ya dan tidak. Menghitung jarak kedekatan dapat ditentukan menggunakan persamaan (1)

Setelah mendapatkan hasil perkalian dan penjumlahan nilai kriteria dengan nilai bobot, kemudian dibagi dengan nilai bobot yang telah di jumlahkan. Untuk mendapatkan hasilnya dapat menggunkan persamaan (2)

Rule basis sistem merupakan salah satu komponen yang ada di dalam sistem pakar. Aturan tersebut biasanya berbentuk IF-THEN. Rule basis sistem atau sistem berbasis aturan yaitu cara untuk menyimpan dan memanipulasi pengetahun untuk menginterprestrasikan informasi dalam cara yang bermanfaat. Kaidah dalam basis pengetahuan adalah sebagai berikut :

\section{Rule 1:}

IF Mulut berbau minuman keras

AND Pusing

AND Sempoyongan

AND Mudah emosi

AND Mual-mual

AND Muntah-muntah

AND Berbicara tidak menentu

AND Gelisah

AND Sering gemetar

AND Wajah kemerah-merahan

AND Penglihatan menurun

AND Kesulitan bernafas

AND Jantung berdetak kencang

AND Kesulitan menelan dan berbicara

AND Muntah darah

AND Wajah bengkak hitam pucat

THEN Anda mengalami gangguan kesehatan ringan dengan nilai probabilitas 35,75\%

Contoh Kasus Lama:

Ada 3 orang pasien bernama Dodi, Rommy dan Donal yang telah melakukan diagnosa sebelumnya dengan masingmasing menjawab pertanyaan sesuai dengan gejala yang dialami. Berikut adalah tabel pertanyaan dan nilai masingmasing gejala: 
Tabel 5. Sampel Kasus Lama

\begin{tabular}{|c|c|c|c|c|}
\hline No & Gejala & K1 & $\mathrm{K} 2$ & K3 \\
\hline 1 & $\begin{array}{l}\text { Apakah mulut anda berbau minuman keras } \\
\text { setelah mengkonsumsi minuman keras? }\end{array}$ & $\mathrm{Ya}$ & $\mathrm{Ya}$ & Ya \\
\hline 2 & $\begin{array}{l}\text { Apakah anda mengalami pusing di bagian } \\
\text { kepala? }\end{array}$ & Ya & Tidak & Tidak \\
\hline 3 & $\begin{array}{l}\text { Apakah anda mengalami sempoyongan } \\
\text { saat berjalan? }\end{array}$ & Ya & Tidak & Tidak \\
\hline 4 & Apakah anda mengalami mudah emosi? & Ya & Tidak & Tidak \\
\hline 5 & Apakah anda merasakan mual-mual? & Ya & Tidak & Tidak \\
\hline 6 & Apakah anda mengalami muntah-muntah? & Ya & Tidak & Tidak \\
\hline 7 & $\begin{array}{l}\text { Apakah anda mengalami berbicara yang } \\
\text { tidak menentu? }\end{array}$ & Tidak & Ya & Tidak \\
\hline 8 & Apakah anda merasakan gelisah? & Tidak & Ya & Tidak \\
\hline 9 & $\begin{array}{l}\text { Apakah anda mengalami keseringan } \\
\text { gemetar pada tubuh saat setelah } \\
\text { mengkonsumsi minuman keras? }\end{array}$ & Tidak & Ya & Ya \\
\hline 10 & $\begin{array}{l}\text { Apakah anda mengalami perubahan pada } \\
\text { wajah menjadi kemerah-merahan? }\end{array}$ & Tidak & Ya & Tidak \\
\hline 11 & $\begin{array}{l}\text { Apakah anda mengalami penglihatan yang } \\
\text { menurun saat setelah mengkonsumsi } \\
\text { minuman keras? }\end{array}$ & Tidak & Ya & Tidak \\
\hline 12 & $\begin{array}{l}\text { Apakah anda mengalami kesulitan } \\
\text { bernafas saat setelah mengkonsumsi } \\
\text { minuman keras? }\end{array}$ & Tidak & Tidak & Ya \\
\hline 13 & $\begin{array}{l}\text { Apakah anda mengalami detak jantung } \\
\text { yang berdetak sangat cepat setelah } \\
\text { mengkonsumsi minuman keras? }\end{array}$ & Tidak & Tidak & Ya \\
\hline 14 & $\begin{array}{l}\text { Apakah anda mengalami kesulitan } \\
\text { menelan dan berbicara? }\end{array}$ & Tidak & Tidak & Ya \\
\hline 15 & Apakah anda mengalami muntah darah? & Tidak & Tidak & Ya \\
\hline 16 & $\begin{array}{l}\text { Apakah anda mengalami perubahan wajah } \\
\text { yang bengkak hitam pucat? }\end{array}$ & Tidak & Tidak & Tidak \\
\hline \multicolumn{2}{|c|}{ Hasil Diagnosa (\%) } & $\begin{array}{l}\text { Ringan } \\
(0 \%-50 \%)\end{array}$ & $\begin{array}{l}\text { Sedang } \\
\quad(51 \%- \\
80 \%)\end{array}$ & $\begin{array}{l}\text { Berat } \\
\quad(81 \%- \\
100 \%)\end{array}$ \\
\hline
\end{tabular}

Soal kasus baru

Topoy datang ke rumah sakit ingin melakukan diagnosa gangguan kesehatan yang dialaminya akibar minuman keras dengan kriteria sebagai berikut:

Tabel 6. Kasus Baru

\begin{tabular}{clc}
\hline No. & \multicolumn{1}{c}{ Gejala } & Pilihan Pasien \\
\hline 1 & $\begin{array}{l}\text { Apakah mulut anda berbau minuman keras } \\
\text { setelah mengkonsumsi minuman keras? }\end{array}$ & Ya \\
2 & $\begin{array}{l}\text { Apakah anda mengalami pusing di bagian kepala? } \\
\text { Apakah anda mengalami sempoyongan saat }\end{array}$ & Tidak \\
& Tidak \\
& berjalan? & Tidak \\
4 & Apakah anda mengalami mudah emosi? & Tidak \\
5 & Apakah anda merasakan mual-mual? & Tidak \\
6 & Apakah anda mengalami muntah-muntah? & Ya \\
7 & Apakah anda mengalami berbicara yang tidak & Tidak \\
& menentu? & Tidak \\
8 & Apakah anda merasakan gelisah? & \\
9 & $\begin{array}{l}\text { Apakah anda mengalami keseringan gemetar pada } \\
\text { tubuh saat setelah mengkonsumsi minuman }\end{array}$ & Tidak \\
& keras? & \\
10 & $\begin{array}{l}\text { Apakah anda mengalami perubahan pada wajah } \\
\text { menjadi kemerah-merahan? }\end{array}$ & Tidak \\
11 & $\begin{array}{l}\text { Apakah anda mengalami penglihatan yang } \\
\text { menurun saat setelah mengkonsumsi minuman }\end{array}$ \\
& keras? & \\
\hline
\end{tabular}




\begin{tabular}{clc}
\hline No. & \multicolumn{1}{c}{ Gejala } & Pilihan Pasien \\
\hline 12 & $\begin{array}{l}\text { Apakah anda mengalami kesulitan bernafas saat } \\
\text { setelah mengkonsumsi minuman keras? }\end{array}$ & Ya \\
13 & $\begin{array}{l}\text { Apakah anda mengalami detak jantung yang } \\
\text { berdetak sangat cepat setelah mengkonsumsi } \\
\text { minuman keras? }\end{array}$ & Ya \\
14 & $\begin{array}{l}\text { Apakah anda mengalami kesulitan menelan dan } \\
\text { berbicara? }\end{array}$ & Ya \\
15 & $\begin{array}{l}\text { Apakah anda mengalami muntah darah? } \\
\text { Apakah anda mengalami perubahan wajah yang } \\
\text { bengkak hitam pucat? }\end{array}$ & Tidak \\
\end{tabular}

Maka untuk menyelesaikan maslah di atas berikut ini adalah Algoritma penyelesaiannya.

1. Menghitung nilai kedekatan tribut kondisi kasus Baru dengan kasus Lama.

Tabel 7. Kedekatan Kasus Baru dan Kasus Lama

\begin{tabular}{|c|c|c|c|c|c|c|c|}
\hline $\mathrm{NO}$ & Gejala & K1 & $\begin{array}{c}\text { BKB } \\
\text { aru }\end{array}$ & K2 & BKL & K.Bobot & NA \\
\hline 1 & $\begin{array}{l}\text { Apakah mulut anda berbau } \\
\text { minuman keras setelah } \\
\text { mengkonsumsi minuman keras? }\end{array}$ & $\mathrm{Ya}$ & 0,9 & $\mathrm{Ya}$ & 0,9 & 1 & $\mathrm{a}$ \\
\hline 2 & $\begin{array}{l}\text { Apakah anda mengalami pusing } \\
\text { di bagian kepala? }\end{array}$ & Tidak & 0,9 & $\mathrm{Ya}$ & 0,9 & 0,5 & $\mathrm{~b}$ \\
\hline 3 & $\begin{array}{l}\text { Apakah anda mengalami } \\
\text { sempoyongan saat berjalan? }\end{array}$ & Tidak & 0,8 & $\mathrm{Ya}$ & 0,8 & 0,5 & $\mathrm{c}$ \\
\hline 4 & $\begin{array}{l}\text { Apakah anda mengalami mudah } \\
\text { emosi? }\end{array}$ & Tidak & 0,8 & $\mathrm{Ya}$ & 0,8 & 0,5 & $\mathrm{~d}$ \\
\hline 5 & $\begin{array}{l}\text { Apakah anda merasakan mual- } \\
\text { mual? }\end{array}$ & Tidak & 0,7 & $\mathrm{Ya}$ & 0,7 & 0,5 & $\mathrm{e}$ \\
\hline 6 & $\begin{array}{l}\text { Apakah anda mengalami } \\
\text { muntah-muntah? }\end{array}$ & Tidak & 0,7 & $\mathrm{Ya}$ & 0,7 & 0,5 & $\mathrm{~F}$ \\
\hline 7 & $\begin{array}{l}\text { Apakah anda mengalami } \\
\text { berbicara yang tidak menentu? }\end{array}$ & Ya & 0,9 & Tidak & 0,9 & 0,25 & $\mathrm{~g}$ \\
\hline 8 & $\begin{array}{l}\text { Apakah anda merasakan } \\
\text { gelisah? }\end{array}$ & Tidak & 0,5 & Tidak & 0,5 & 0 & $\mathrm{~h}$ \\
\hline 9 & $\begin{array}{l}\text { Apakah anda mengalami } \\
\text { keseringan gemetar pada tubuh } \\
\text { saat setelah mengkonsumsi } \\
\text { minuman keras? }\end{array}$ & Tidak & 0,4 & Tidak & 0,4 & 0 & $\mathrm{i}$ \\
\hline 10 & $\begin{array}{l}\text { Apakah anda mengalami } \\
\text { perubahan pada wajah menjadi } \\
\text { kemerah-merahan? }\end{array}$ & Tidak & 0,6 & Tidak & 0,6 & 0 & $\mathrm{j}$ \\
\hline 11 & $\begin{array}{l}\text { Apakah anda mengalami } \\
\text { penglihatan yang menurun saat } \\
\text { setelah mengkonsumsi } \\
\text { minuman keras? }\end{array}$ & Tidak & 0,4 & Tidak & 0,4 & 0 & K \\
\hline 12 & $\begin{array}{l}\text { Apakah anda mengalami } \\
\text { kesulitan bernafas saat setelah } \\
\text { mengkonsumsi minuman keras? }\end{array}$ & $\mathrm{Ya}$ & 0,7 & Tidak & 0,7 & 0,25 & 1 \\
\hline 13 & $\begin{array}{l}\text { Apakah anda mengalami detak } \\
\text { jantung yang berdetak sangat } \\
\text { cepat setelah mengkonsumsi } \\
\text { minuman keras? }\end{array}$ & $\mathrm{Ya}$ & 0,9 & Tidak & 0,9 & 0,25 & $\mathrm{~m}$ \\
\hline 14 & $\begin{array}{l}\text { Apakah anda mengalami } \\
\text { kesulitan menelan dan } \\
\text { berbicara? }\end{array}$ & Ya & 0,4 & Tidak & 0,4 & 0,25 & $\mathrm{n}$ \\
\hline 15 & $\begin{array}{l}\text { Apakah anda mengalami } \\
\text { muntah darah? }\end{array}$ & Tidak & 0,3 & Tidak & 0,3 & 0 & o \\
\hline 16 & $\begin{array}{l}\text { Apakah anda mengalami } \\
\text { perubahan wajah yang bengkak } \\
\text { hitam pucat? }\end{array}$ & Tidak & 0,1 & Tidak & 0,1 & 0 & $\mathrm{p}$ \\
\hline
\end{tabular}


Keterangan:

K1 : Kriteria Satu

K2 : Kriteria Dua

BK Baru : Bobot Ktiteria Baru

BKL : Bobot Kriteria Lama

K.Bobot : Kedekatan Bobot

NA : Nilai Atribut

Perhitungan jarak kemiripan kasus baru dengan kasus lama:

$$
\begin{aligned}
& \text { Jarak }=(a * a)+(b * b)+(c * c)+(d * d)+\left(e^{*} e\right)+(f * f)+(g * g)+(h * h)+(i * i)+(j * j)+(k * k)+(1 * 1)+ \\
& (\mathrm{m} * \mathrm{~m})+(\mathrm{n} * \mathrm{n})+(\mathrm{o} * \mathrm{o})+(\mathrm{p} * \mathrm{p}) \\
& a+b+c+d+e+f+g+h+i+j+k+l+m+n+o+p
\end{aligned}
$$

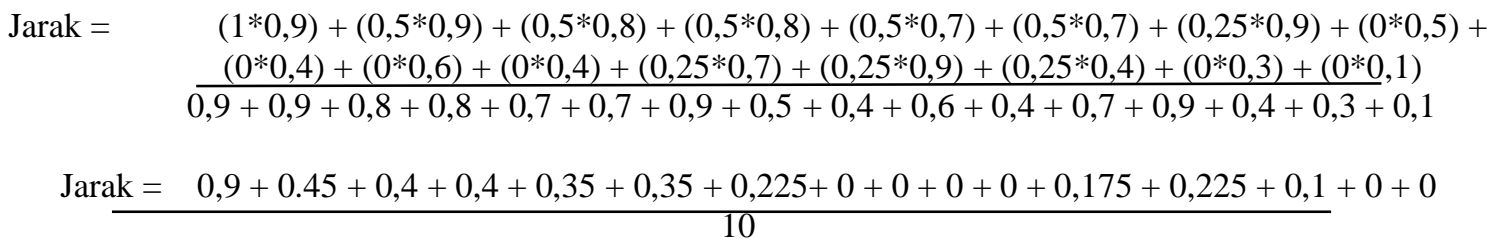

\begin{tabular}{|c|c|c|c|c|c|c|c|}
\hline $\mathrm{NO}$ & Gejala & $\mathrm{K} 1$ & BKBaru & $\mathrm{K} 2$ & $\mathrm{BKL}$ & K.Bobot & NA \\
\hline 1 & $\begin{array}{l}\text { Apakah mulut anda berbau minuman } \\
\text { keras setelah mengkonsumsi } \\
\text { minuman keras? }\end{array}$ & $\mathrm{Ya}$ & 0,9 & Ya & 0,9 & 1 & $\mathrm{a}$ \\
\hline 2 & $\begin{array}{l}\text { Apakah anda mengalami pusing di } \\
\text { bagian kepala? }\end{array}$ & Tidak & 0,9 & Tidak & 0,9 & 0 & $\mathrm{~b}$ \\
\hline 3 & $\begin{array}{l}\text { Apakah anda mengalami } \\
\text { sempoyongan saat berjalan? }\end{array}$ & Tidak & 0,8 & Tidak & 0,8 & 0 & $\mathrm{c}$ \\
\hline 4 & $\begin{array}{l}\text { Apakah anda mengalami mudah } \\
\text { emosi? }\end{array}$ & Tidak & 0,8 & Tidak & 0,8 & 0 & $\mathrm{~d}$ \\
\hline 5 & Apakah anda merasakan mual-mual? & Tidak & 0,7 & Tidak & 0,7 & 0 & e \\
\hline 6 & $\begin{array}{l}\text { Apakah anda mengalami muntah- } \\
\text { muntah? }\end{array}$ & Tidak & 0,7 & Tidak & 0,7 & 0 & $\mathrm{f}$ \\
\hline 7 & $\begin{array}{l}\text { Apakah anda mengalami berbicara } \\
\text { yang tidak menentu? }\end{array}$ & Ya & 0,9 & Ya & 0,9 & 1 & $\mathrm{~g}$ \\
\hline 8 & Apakah anda merasakan gelisah? & Tidak & 0,5 & Ya & 0,5 & 0,5 & $\mathrm{H}$ \\
\hline 9 & $\begin{array}{l}\text { Apakah anda mengalami keseringan } \\
\text { gemetar pada tubuh saat setelah } \\
\text { mengkonsumsi minuman keras? }\end{array}$ & Tidak & 0,4 & Ya & 0,4 & 0,5 & $\mathrm{i}$ \\
\hline 10 & $\begin{array}{l}\text { Apakah anda mengalami perubahan } \\
\text { pada wajah menjadi kemerah- } \\
\text { merahan? }\end{array}$ & Tidak & 0,6 & Ya & 0,6 & 0,5 & $\mathrm{j}$ \\
\hline 11 & $\begin{array}{l}\text { Apakah anda mengalami penglihatan } \\
\text { yang menurun saat setelah } \\
\text { mengkonsumsi minuman keras? }\end{array}$ & Tidak & 0,4 & Ya & 0,4 & 0,5 & $\mathrm{k}$ \\
\hline 12 & $\begin{array}{l}\text { Apakah anda mengalami kesulitan } \\
\text { bernafas saat setelah mengkonsumsi } \\
\text { minuman keras? }\end{array}$ & Ya & 0,7 & Tidak & 0,7 & 0,5 & $\mathrm{~L}$ \\
\hline 13 & $\begin{array}{l}\text { Apakah anda mengalami detak } \\
\text { jantung yang berdetak sangat cepat } \\
\text { setelah mengkonsumsi minuman } \\
\text { keras? }\end{array}$ & Ya & 0,9 & Tidak & 0,9 & 0,25 & $\mathrm{~m}$ \\
\hline 14 & $\begin{array}{l}\text { Apakah anda mengalami kesulitan } \\
\text { menelan dan berbicara? }\end{array}$ & Ya & 0,4 & Tidak & 0,4 & 0,25 & \\
\hline
\end{tabular}

Jarak $=\frac{3,575}{10}$
Jarak $=0,3575$

Tabel 8. Kedekatan Kasus Baru dan Kasus Lama 


\begin{tabular}{clcccccc}
\hline NO & \multicolumn{1}{c}{ Gejala } & K1 & BKBaru & K2 & BKL & K.Bobot & NA \\
\hline 15 & $\begin{array}{l}\text { Apakah anda mengalami muntah } \\
\text { darah? }\end{array}$ & Tidak & 0,3 & Tidak & 0,3 & 0 & \\
16 & $\begin{array}{l}\text { Apakah anda mengalami perubahan } \\
\text { wajah yang bengkak hitam pucat? }\end{array}$ & Tidak & 0,1 & Tidak & 0,1 & 0 & p \\
\hline
\end{tabular}

Perhitungan jarak kemiripan kasus baru dengan kasus lama:

Jarak $=$

$$
\left(a^{*} \mathrm{a}\right)+\left(b^{*} \mathrm{~b}\right)+(\mathrm{c} * \mathrm{c})+\left(\mathrm{d}^{*} \mathrm{~d}\right)+\left(\mathrm{e}^{*} \mathrm{e}\right)+\left(\mathrm{f}^{*} \mathrm{f}\right)+(\mathrm{g} * \mathrm{~g})+(\mathrm{h} * \mathrm{~h})+\left(\mathrm{i}^{* \mathrm{i}}\right)+\left(\mathrm{j}^{*} \mathrm{j}\right)+\left(\mathrm{k}^{*} \mathrm{k}\right)+\left(\mathrm{l}^{*} \mathrm{l}\right)+
$$
$\left(\mathrm{m}^{*} \mathrm{~m}\right)+(\mathrm{n} * \mathrm{n})+(\mathrm{o} * \mathrm{o})+(\mathrm{p} * \mathrm{p})$

$$
a+b+c+d+e+f+g+h+I+j+k+1+m+n+o+p
$$

$$
\begin{gathered}
\text { Jarak }=\begin{array}{r}
(1 * 0,9)+(0 * 0,9)+(0 * 0,8)+(0 * 0,8)+(0 * 0,7)+(0 * 0,7)+(1 * 0,9)+(0,5 * 0,5)+(0,5 * 0,4)+ \\
\frac{(0,5 * 0,6)+(0,5 * 0,4)+(0,5 * 0,7)+(0,25 * 0,9)+(0,25 * 0,4)+(0 * 0,3)+(0 * 0,1)}{0,9+0,9+0,8+0,8+0,7+0,7+0,9+0,5+0,4+0,6+0,4+0,7+0,9+0,4+0,3+0,1} \\
\text { Jarak }=0,9+0+0+0+0+0+0,9+0,25+0,2+0,3+0,2+0,35+0,225+0,1+0+0
\end{array}
\end{gathered}
$$

\begin{tabular}{|c|c|c|c|c|c|c|c|}
\hline $\mathrm{NO}$ & Gejala & K1 & BKBaru & $\mathrm{K} 2$ & BKL & K.Bobot & NA \\
\hline 1 & $\begin{array}{l}\text { Apakah mulut anda berbau } \\
\text { minuman keras setelah } \\
\text { mengkonsumsi minuman keras? }\end{array}$ & $\mathrm{Ya}$ & 0,9 & $\mathrm{Ya}$ & 0,9 & 1 & $\mathrm{a}$ \\
\hline 2 & $\begin{array}{l}\text { Apakah anda mengalami pusing } \\
\text { di bagian kepala? }\end{array}$ & Tidak & 0,9 & Tidak & 0,9 & 0 & $\mathrm{~b}$ \\
\hline 3 & $\begin{array}{l}\text { Apakah anda mengalami } \\
\text { sempoyongan saat berjalan? }\end{array}$ & Tidak & 0,8 & Tidak & 0,8 & 0 & $\mathrm{c}$ \\
\hline 4 & $\begin{array}{l}\text { Apakah anda mengalami mudah } \\
\text { emosi? }\end{array}$ & Tidak & 0,8 & Tidak & 0,8 & 0 & d \\
\hline 5 & $\begin{array}{l}\text { Apakah anda merasakan mual- } \\
\text { mual? }\end{array}$ & Tidak & 0,7 & Tidak & 0,7 & 0 & $\mathrm{e}$ \\
\hline 6 & $\begin{array}{l}\text { Apakah anda mengalami muntah- } \\
\text { muntah? }\end{array}$ & Tidak & 0,7 & Tidak & 0,7 & 0 & $\mathrm{f}$ \\
\hline 7 & $\begin{array}{l}\text { Apakah anda mengalami } \\
\text { berbicara yang tidak menentu? }\end{array}$ & Ya & 0,9 & Tidak & 0,9 & 0,25 & $\mathrm{~g}$ \\
\hline 8 & Apakah anda merasakan gelisah? & Tidak & 0,5 & Tidak & 0,5 & 0 & $\mathrm{~h}$ \\
\hline 9 & $\begin{array}{l}\text { Apakah anda mengalami } \\
\text { keseringan gemetar pada tubuh } \\
\text { saat setelah mengkonsumsi } \\
\text { minuman keras? }\end{array}$ & Tidak & 0,4 & Tidak & 0,4 & 0 & I \\
\hline 10 & $\begin{array}{l}\text { Apakah anda mengalami } \\
\text { perubahan pada wajah menjadi } \\
\text { kemerah-merahan? }\end{array}$ & Tidak & 0,6 & Tidak & 0,6 & 0 & $\mathrm{j}$ \\
\hline 11 & $\begin{array}{l}\text { Apakah anda mengalami } \\
\text { penglihatan yang menurun saat } \\
\text { setelah mengkonsumsi minuman } \\
\text { keras? }\end{array}$ & Tidak & 0,4 & Tidak & 0,4 & 0 & $\mathrm{k}$ \\
\hline 12 & $\begin{array}{l}\text { Apakah anda mengalami } \\
\text { kesulitan bernafas saat setelah } \\
\text { mengkonsumsi minuman keras? }\end{array}$ & Ya & 0,7 & $\mathrm{Ya}$ & 0,7 & 1 & 1 \\
\hline 13 & $\begin{array}{l}\text { Apakah anda mengalami detak } \\
\text { jantung yang berdetak sangat } \\
\text { cepat setelah mengkonsumsi } \\
\text { minuman keras? }\end{array}$ & Ya & 0,9 & $\mathrm{Ya}$ & 0,9 & 1 & M \\
\hline
\end{tabular}

Jarak $=\frac{3,425}{10}$

Jarak $=0,3425$

Tabel 9. Kedekatan Kasus Baru dan Kaus Lama 


\begin{tabular}{|c|c|c|c|c|c|c|c|}
\hline $\mathrm{NO}$ & Gejala & K1 & BKBaru & $\mathrm{K} 2$ & BKL & K.Bobot & NA \\
\hline 14 & $\begin{array}{l}\text { Apakah anda mengalami } \\
\text { kesulitan menelan dan berbicara? }\end{array}$ & $\mathrm{Ya}$ & 0,4 & $\mathrm{Ya}$ & 0,4 & 1 & $\mathrm{n}$ \\
\hline 15 & $\begin{array}{l}\text { Apakah anda mengalami muntah } \\
\text { darah? }\end{array}$ & Tidak & 0,3 & $\mathrm{Ya}$ & 0,3 & 0,5 & $\mathrm{o}$ \\
\hline 16 & $\begin{array}{l}\text { Apakah anda mengalami } \\
\text { perubahan wajah yang bengkak } \\
\text { hitam pucat? }\end{array}$ & Tidak & 0,1 & $\mathrm{Ya}$ & 0,1 & 0,5 & $\mathrm{p}$ \\
\hline
\end{tabular}

Perhitungan jarak kemiripan kasus baru dengan kasus lama:

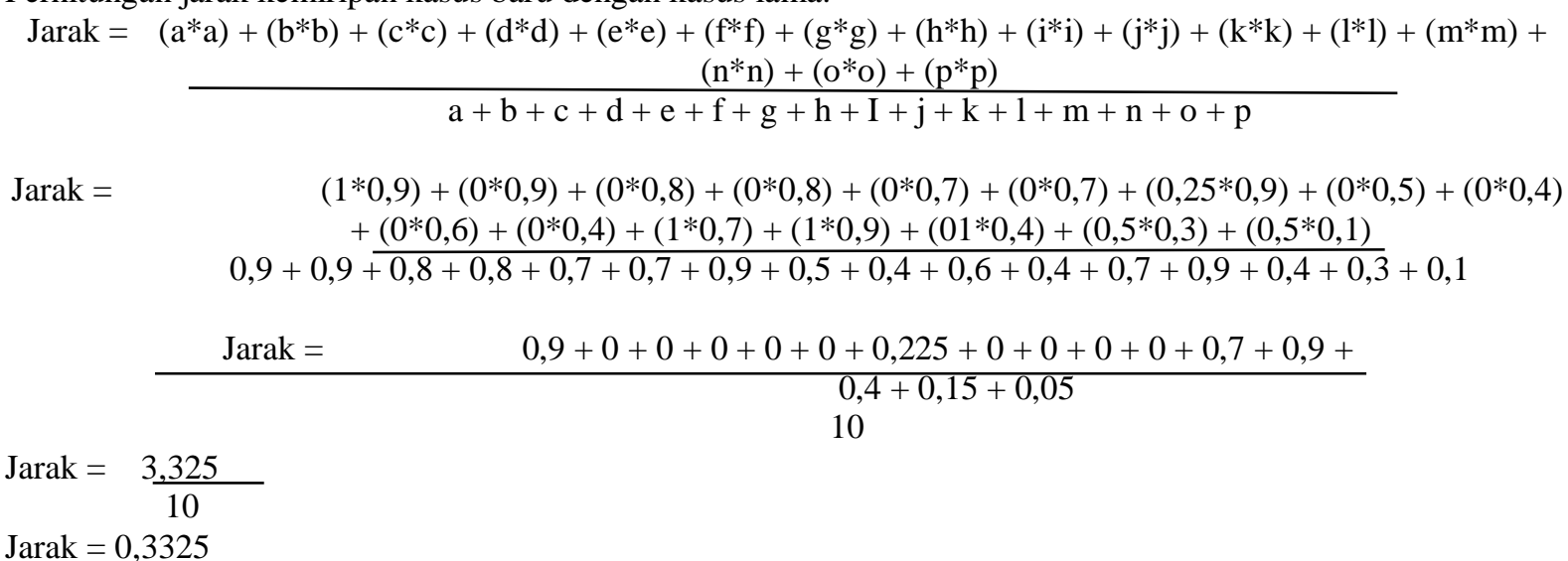

Dari langkah 1 sampai 3 dapat diketahui nilai kedekatannya, berikut ini adalah rekapitulasi.

Tabel 10. Rekapitulasi Nilai Kedekatan

\begin{tabular}{ccc}
\hline NO & Kasus & Nilai Kedekatan(\%) \\
\hline 1 & Kasus 1 & 0,3575 \\
2 & Kasus 2 & 0,3425 \\
3 & Kasus 3 & 0,3325 \\
\hline
\end{tabular}

Berdasarkan tabel di atas untuk nilai kedekatan tertinggi adalah pada nilai Kasus 1. Jadi, untuk soal di atas maka pengguna minuman keras pada nilai atribut hasil diagnosa dengan nilai kedekatan $0,3575 \%(0,3575 * 100=$ $35,75 \%)$ "Ringan".

\section{IMPLEMENTASI}

Untuk memastikan program berjalan dengan baik atau tidak maka di lakukan pengujian pada program, Adapun tahap pengujiannya adalah sebagai berikut :

\section{Form Login}

Form login berfungsi sebagai form awal dari aplikasi sistem pakar yang akan memulai semua yang akan dibutuhkan, adapun desainnya sebagai berikut:

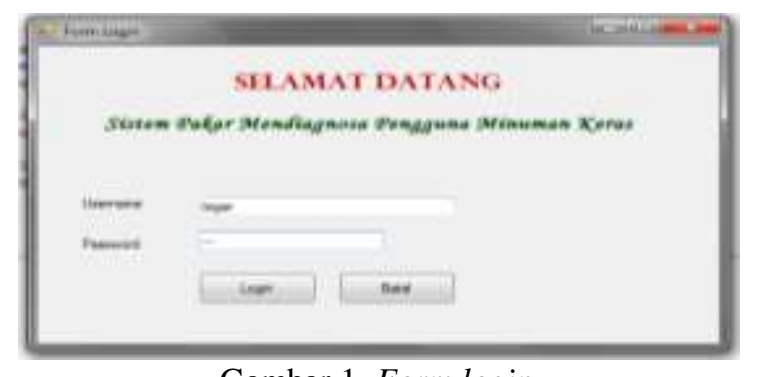

\section{Form Menu Utama}

Gambar 1. Form login

Menu utama berfungsi sebagai induk dari semua form yang ada yang menampilakan menu-menu yang akan di pilih, adapun desainnya sebagai berikut: 


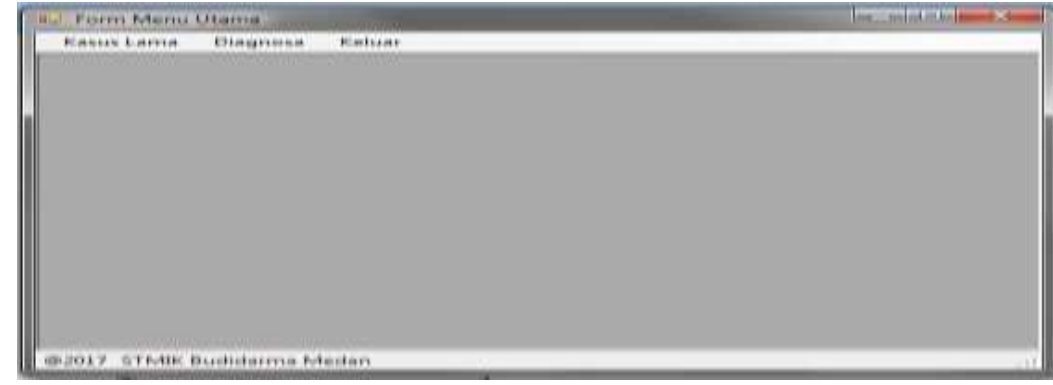

Gambar 2. Form Menu Utama

\section{Form Kasus Lama}

Form Kasus Lama berfungsi untuk menyimpan history hasil diagnosa pasien ke kolom yang telah disediakan yang akan langsung tersimpan ke dalam database, adapun desainnya sebagai berikut:

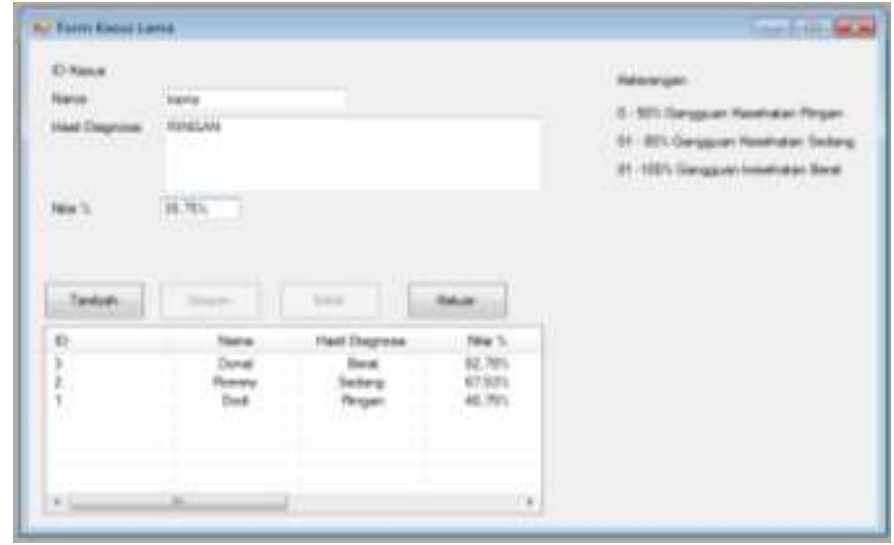

Gambar 3. Form Kasus Lama

\section{Form Pertanyaan}

Form Pertanyaan berfungsi untuk menggali data yang dialami pasien yang menampikan beberapa pertanyaan yang akan di jawab oleh pasien dengan adanya pilihan yang disediakan, adapun desainnya sebagai berikut:

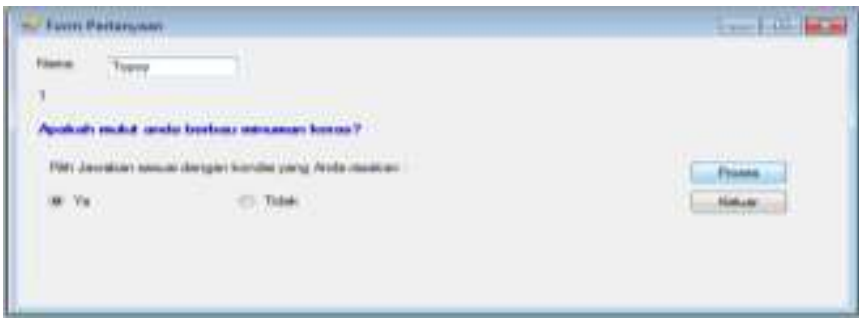

Gambar 4. Form Pertanyaan

\section{Form Hasil Diagnosa}

Form hasil diagnosa berfungsi untuk menampilkan hasil dari pertanyaan yang di jawab oleh pasien yang memberikan hasil dari yang pasien alami, adapun desainnya sebagai berikut:

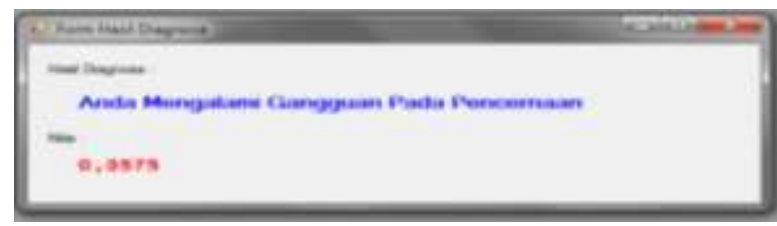

Gambar 5. Form Hasil Diagnosa

\section{KESIMPULAN}

Setelah melakukan penelitian dan juga berdasarkan referensi-referensi yang ada, data dan analisa serta melalui fakta yang telah diuraikan pada bab-bab terdahulu, maka penulis mengangkat kesimpulan sebagai berikut : 
1. Gejala pengguna minuman keras diperoleh dari pakar setelah itu gejala-gejala yang ditimbulkan tersebut dibobotkan untuk menentukan kriteria gangguan kesehtan pengkonsumsi minuman keras dalam tingkatan ringan, sedang dan berat.

2. Sistem pakar ini menerapkan Metode Nearest Neighbor untuk mendiagnosa gangguan kesehatan pengguna minuman keras adalah dengan mencari masing-masing kriteria pengguna minuman keras tersebut dan kemudian digunakan untuk perhitungan jarak kedekatan. Maka dapat mengetahui hasil perhitungan dari Metode Nearest Neighbor tersebut.

3. Sistem pakar mendiagnosa gangguan kesehatan pengguna minuman keras dirancang dengan tampilan Microsoft Visual Basic 2008 yang memiliki beberapa tampilan berikut: tampilan form login, form menu utama, form kasus lama, form pertanyaan, dan form hasil diagnosa.

\section{REFERENCES}

[1] Mei Lestari, 2014, issn:1971-276X, Penerapan Algoritma Klasifikasi Nearest Neighbor(K-NN)Untuk Mendeteksi Penyakit Jantung

[2] Hamdani, Vol 5 No. 2 Juli 2010 13Sistem Pakar Untuk Diagnosa Penyakit Mata Pada Manusia

[3] Muhammad Arhami, "Konsep Dasar Sistem Pakar", 2010.

[4] Sutojo,S.Si,S.Kom, Edy Mulyanto,S.Si, M.Kom, Dr.Vincen Suhartono, "Kecerdasan Buatan”, (2011)

[5] Kamus Besar Bahasa Indonesia

[6] Jatisi, Vol. 1 No. 1 September 2014, Analisis Prediksi Tingkat Pengunduran Diri Mahasiswa dengan Metode K-Nearest Neighbor, ISSN : 2407-4322

[7] UPN "Veteran" Yogyakarta, 18 Mei 2013, Aa Zezen Zaenal Abidin, IMPLEMENTASI ALGORITMA K-NEAREST NEIGHBORS UNTUK MENENTUKAN KEMUNGKINAN TINGKAT KETERCAPAIAN KOMPETENSI PEMBELAJARANKETERAMPILAN KOMPUTER DAN PENGELOLAAN INFORMASI, ISSN: 1979-2328

[8] M. Syahril, N.A. Hasibuan, P. Pristiwanto, PENERAPAN METODE DEMPSTER SHAFER DALAM MENDIAGNOSA PENYAKIT BELL'S PALSY, JURIKOM (Jurnal Ris. Komputer). 3 (2016).

[9] Asep Subhi dan Ahmad Taufik,'Pengertian Minuman Keras", 2004:103

[10] dr.M Sitepu,2017

[11] Rosa A.S dan M. Salahuddin, Rekayasa Perangkat Lunak, 2011:134

[10] I. Sumatorno, D. Arisandi, A.P.U. Siahaan, M. Mesran, Expert System of Catfish Disease Determinants Using Certainty Factor Method, Int. J. Recent Trends Eng. Res. 3 (2017) 202-209. doi:10.23883/IJRTER.2017.3405.TCYZ2.

[11] N.A. Hasibuan, K. Yusmiarti, F.T. Waruwu, R. Rahim, Expert systems with genetics probability, Int. J. Res. Sci. Eng. 3 (2017) 112116.

[12] M. Mesran, M. Syahrizal, S. Suginam, N. Kurniasih, A.D. Gs, A.S. Ahmar, R. Rahim, Expert System for Disease Risk Based on Lifestyle with Fuzzy Mamdani, Int. J. Eng. Technol. 7 (2018) 88-91. doi:10.14419/ijet.v7i2.3.12622.

[13] Asep Subhi dan Ahmad Taufik,"Pengertian Minuman Keras", 2004:103

[14] dr.M Sitepu,2017

[15] Rosa A.S dan M. Salahuddin, Rekayasa Perangkat Lunak, 2011:134

[16] H.M Jugianto,Analisa Sistem Oprasi,Andi, Yogyakarta,2000

[17] Herry Raditya Wibowo, Jubilee Entrprice, Visual Basik Database, 2014,27.

[18] http://dosenit.com/kuliah-it/database/pengertian-sistem-basis-data-menurut-para-ahli

[19] Yeni K dan Devie R.A,’Pemrograman Basis Data Berbasis Web Menggunakan PHP dan MYSQL", 2011:153 